\title{
Balkanologie
}

Balkanologie Revue d'études pluridisciplinaires

Vol. III, n² | 1999

Volume III Numéro 2

\section{South-Eastern Europe : History, Concepts, Boundaries}

\section{Wendy Bracewell and Alex Drace-Francis}

\section{(2) OpenEdition}

1 Journals

Édition électronique

URL : http://journals.openedition.org/balkanologie/741

DOI : 10.4000/balkanologie.741

ISSN : 1965-0582

Éditeur

Association française d'études sur les Balkans (Afebalk)

Édition imprimée

Date de publication : 1 décembre 1999

ISSN : 1279-7952

\section{Référence électronique}

Wendy Bracewell and Alex Drace-Francis, « South-Eastern Europe : History, Concepts, Boundaries », Balkanologie [En ligne], Vol. III, n² | 1999, mis en ligne le 22 juin 2010, consulté le 17 décembre 2020. URL : http://journals.openedition.org/balkanologie/741 ; DOI : https://doi.org/10.4000/balkanologie. 741

Ce document a été généré automatiquement le 17 décembre 2020.

(c) Tous droits réservés 


\title{
South-Eastern Europe : History, Concepts, Boundaries
}

\author{
Wendy Bracewell and Alex Drace-Francis
}

1 This issue of Balkanologie gathers together a selection of papers presented at a special conference organized by the Centre for South-East European Studies, London, dedicated to exploring the idea of South-Eastern Europe.

2 There is no generally agreed definition of South-Eastern Europe, but there are many reasons for this uncertainty. The most banal reason is that Europe is not symmetrical in shape, and therefore does not lend itself with ease to division according to the points of the compass. A second obvious reason is that the physical map of Europe differs from its political configurations, and the relation between land and people is never simple. A third reason is that numerous alternative names have been given to various parts of the South-East of Europe, and these have generally had preference. A fourth is that Europe is believed by many to have not only an East, West, North and South, but (and increasingly in recent years) a Centre. This possibility, however remote, naturally affects the size of the presumed South-East.

People have also advanced definitions based not on whether the region is real, but whether it is good and beautiful, or bad and ugly; worth invading, or best left well alone; peaceful or warlike ; ethically uncultivable, or ripe for improvement; similar or different, both to itself and to other regions. This problem is old: one of the most popular and widely-disseminated texts of the mediaeval world, composed in either the $5^{\text {th }}$ or $6^{\text {th }}$ centuries AD, illustrates the problem as well as any, with the following account of the contrasts to be found in South-Eastern Europe :

In this part [of the world - one of the geographical klimata] are to be found the Slavs and the Phisonites, also called Danubians. The former take pleasure in eating women's breasts filled with milk, and they break new-born babies against the rocks like mice. The latter, on the other hand, avoid consuming even meat which can be eaten lawfully and without reproach. The one are insubordinate, independent, reck no master and frequently kill their chieftain when at table or travelling; they eat foxes, wild cats and boar and call out to each other with wolf-cries. Do not the 
others refrain from excessive eating, and do they not submit to the authority of the first comer ? $^{1}$ the 1990s has been just such a period, and much consideration has recently been given to interrogating the categories whereby regions are defined. After 1989, which was assumed by some to mark "the end of history", came a kind of "rebirth of geography", which proposed that the world's affairs would be affected more by profound cultural differences, clearly divisible according to region, than by hard political or ideological considerations ${ }^{4}$. This controversial thesis led scholars of many disciplines to reexamine - or to examine for the first time, if they had not already done so - the bases upon which regions are theorized and proposed. Critical histories of our region were produced $^{5}$ and ahistorical judgements were criticized ${ }^{6}$, confrontations anticipated and myths of confrontation exposed7. Fashionable words included "spectre", "borderlands", "invention"10, "nationalism"11. Geometry became tautologically multiple, and ethnic hatreds ancient.

The convenors of the conference, who are placing this selection before the public hoped perhaps to find a way out of the spiralling vacuum of metaphors and the Krise der Kreisen by asking area specialists to consider the question of South-Eastern Europe in terms of a particular discipline. For not only the world but the domain of academic enquiry is presupposed to divide into areas: history, geography, anthropology, literature, linguistics, politics, and so forth. It was a $19^{\text {th }}$ century conception that these "disciplines" would contribute, each in its own way and according to its means, to the clarification of such problems as the one we faced. Thus, the problem of how to define an area would be elucidated by an appeal to distinct but well-defined "spheres" of analysis, and the nature of a place would depend on a separate consideration of its language, customs, history, races, literature, and other criteria (or lack thereof). These points would simply be added up to provide an adequate account of a given people or region.

\section{Debates on definitions}

But there were obvious drawbacks to this approach. Regions were defined according to one type of knowledge : the Balkans was said to be characterized narrowly according to

Balkanologie, Vol. III, n² | 1999 
religion, or to selected common linguistic or ethnic factors, while factors of diversity were ignored. Furthermore, the boundaries generated by one set of disciplinary criteria did not coincide with other definitions, leading to border disputes among area specialists.

Increasingly the Golden Calves of the traditional disciplines have been melted down in the late $20^{\text {th }}$ century, without being recast into one larger graven image. Scholars congregate in new, less exclusive churches presided over by the deity of "interdisciplinarity". But as far as South-Eastern European studies were concerned, this process has been paradoxically difficult. On the one hand, many South-East European scholars, faced as they were with the paucity of sources (and the frequent need to improvise legitimacies for various causes) showed a remarkable versatility at an early stage, combining ethnography and jurisprudence, archaeology and study of religion, paleolinguistics with anthropology : all in the search for valid arguments. On the other hand, the problems of institution-building, whether in impoverished South-East European states or in Western universities, led to intense competition over resources and conflicting claims between disciplinary endeavours. Later on, notably in the 1980 s and early 1990s, some scholars of the area provided valuable critiques of the roles of individual disciplines (and the competition between them) in developing national ideologies in South-Eastern Europe ${ }^{12}$. Nevertheless, the same specialists do not hesitate to reclaim the importance of their particular furrow for the welfare of the field as a whole ${ }^{13}$. An important debate between Ernest Gellner and Edward W. Said over culture and orientalism, relevant to our discussion on region, degenerated into a spat about discipline ${ }^{14}$; while some interesting ripples of irritation over discipline are presently corrugating the ocean of Greek studies ${ }^{15}$. Such debates can contribute to a healthy awareness of the specificities of individual disciplines - but it is still the task of knowing our subject in all its complexity, and not only the methods, that should command our attention.

In spite of their territorial squabbles, the different disciplinary approaches have shared problems in dealing with South-Eastern Europe. One of these has been the tendency to analyze the region in terms of models and theories developed elsewhere, with the result that South-Eastern Europe is often evaluated in terms of its likeness to or deviation from Western Europe : hence discussions of whether the Ottoman system was feudal or not; of Balkan "backwardness" ; of "transition to democracy". Not only are the questions framed inappropriately ; the comparison often attributes a doubtful unity and coherence to Western Europe, obliterating its diversity and changing character ${ }^{16}$. At the same time, identifying South-Eastern Europe as a unit of regional comparison in relation to the West imposes an emphasis on its commonalities and cohesiveness, at the expense of its own variety and complexity.

\section{What criteria ?}

11 How then might we define and understand the region? Different disciplines suggest different hermeneutic approaches. The centrality of history is perhaps inevitable, given the fact that time came to constitute a fundamental category framing modern existence, alongside space, and will not be easily unlearned or forgotten. However, it is often precisely those who most loudly proclaim the importance of history who degrade it by giving it the narrowest definition, confining themselves to a history of political 
personalities and events ${ }^{17}$. And recent claims to make the history of Europe more "total", in the new international context, ignore that region which is our concern ${ }^{18}$. Even some excellent Europe-wide studies dedicated to that supposedly Balkan subject par excellence which is nationalism, fail to take account of the South-Eastern European region in detail ${ }^{19}$. At the same time, the focus on the nation as the fundamental category of historical narrative has deflected attention from other significant units, such as the wider region (as well as the sub-national, the provincial, the local). Even attempts to approach the past on a broad regional scale quite often become parallel national histories rather than truly comparative efforts ${ }^{20}$.

But the question of what criteria should frame a discussion of South-East European history has many possible answers. Should the definition arise from a series of shared structures and attitudes, the legacy of a common past? In this case, historical analysis should probably proceed within the essentially political framework of empires, states and other administrative units - obviating the need for a separate, South-East European unit of analysis ${ }^{21}$. Or should the area be understood as an arena of interaction, its coherence (if not unity) defined in terms of centuries of contact, conflict and coexistence? This approach is typified by frontier studies, exploring the character of zones united as much as divided by their defining boundaries ${ }^{22}$. Or the area could be approached as a framework for comparison. This would follow Marc Bloch's dictum that societies that share common linguistic, political, religious, economic or historical spaces are the best subject for comparative analysis, since they offer the best opportunity for identifying the meaningful similarities and differences ${ }^{23}$.

In fact the admission of the "historical imperative" does not make the problem of defining South Eastern Europe any more clear cut. To a great extent the choice of criteria depends on the prior intentions of the researcher. In this connection it is worth asking how far the centrality of history in discussion of South-Eastern Europe is also a matter of reading present-day preoccupations and purposes into the past ${ }^{24}$. The ways that versions of history have been put into the service of present politics have been repeatedly addressed, not only by Western scholars ${ }^{25}$. Appeals to the past have also framed visions of the region, from both within and without. Such claims - and their foundations - are now coming in for sustained criticism, in the hope of greater intellectual rigour and better official policies. It is open to question how far the second aim is realistic. One of the most learned and influential Western historians of the region, Noel Malcolm, has provided thoroughgoing critiques of "myths" affecting the political crises in Bosnia and Kosovo, and attacked the misleading appeals to history by the actors in these conflicts. Although his work has brought many useful clarifications, Malcolm's definition of "myth" simply in terms of "historical untruth" is not sufficient to understand, let alone to prevent, ongoing conflicts. It may even leave the door open for new myths to enter the scene ${ }^{26}$. The questions of Bosnia and Kosovo are not (or not only) ones of "what really happened", but also ones of why different versions of the past continue to hold the meanings that they do, and of why such importance is attributed to these meanings.

14 If a sense of historicity is important to attempts to define South-Eastern Europe, a sense of diversity and conflicting patterns of culture, religion and language is no less necessary. This is especially relevant to attempts to define South-Eastern Europe in terms of "culture". Grand regional schemes such as those elaborated by the Serbian geographer Jovan Cvijić, or the slightly more limited ethnic and national classifications 
proposed by his successors, singled out common "ethno-psychological" characteristics shaped by shared historical experience and specific modes of subsistence, ultimately derived from a particular geo-physical environment. Similarly, the Romanian historian Nicolae Iorga identified the development of rural social institutions in South-Eastern Europe as the basis of a common regional character ${ }^{27}$. The problem is agreeing on which particular traits are decisive in marking community and demonstrating regional unity ; and on how far they override political, religious or linguistic difference.

\section{Balkan culture}

A different approach to the issue of diversity is that proposed by Traian Stoianovich, in his Balkan Worlds, which attempts to place difference within a broader unity in a way that parallels Fernand Braudel's treatment of the Mediterranean - treating SouthEastern Europe as speaking with many voices, its history the sum of many individual histories, and seeing the Balkans as a microcosm and emblem of a divided Europe. But Stoianovich's Balkans are far less clearly defined than Braudel's Mediterranean ${ }^{28}$. Again, the problem remains precisely what is specifically Balkan about the area and its culture(s), and is there anything that holds its diversity together?

A recent and important article by the Greek scholar Paschalis M. Kitromilides, which constitutes a valiant and fascinating attempt to assess the term "Balkan Mentality", takes up some of these issues ${ }^{29}$. Kitromilides dates the term "Balkan Mentality" to its usage by Cvijić in 1918, and remarks on how the latter's conceptualization of mentalité influenced that of Braudel. He then rejects attempts to argue from ethnographic evidence in favour of either unity or specificity, citing both ethnic diversity and the fact that such materials can also be found elsewhere. Kitromilides goes on to criticize the notion of mentalité for its lack of historicity, arguing that a "mentality" cannot be attributed to anything but specific historical periods. Asserting that the emergence of nationalism in the $19^{\text {th }}$ century precluded the possibility of any common Balkan mentality, he chooses to focus on three men, all Orthodox intellectuals of the mideighteenth to the early $19^{\text {th }}$ century, and declares that their outlook on the world is the closest one may come to a Balkan mentality. A fascinating account of their lives is laid before us : but a number of basic difficulties are not addressed. A "Balkan mentality" is subsumed to the idea of a set of transnational loyalties and to "the "mentality" of Balkan Orthodoxy, which, few will disagree I am sure, primarily defines religious belief in Southeastern Europe $»^{30}$. But the idea of mentalité is not reducible either to religious belief or to transnational consciousness. Furthermore, Orthodoxy was neither the sole religion in South-Eastern Europe, nor confined to it ${ }^{31}$. One may also object that Kitromilides ignores the fact that the Orthodox church both preserved and stimulated separate traditions within different regions of the Balkans ${ }^{32}$. This raises very pointedly the question of which divisions (ethno-linguistic? political? class? religious?) preclude a shared mentality and under what circumstances. If national differences annul a common mentality in the $19^{\text {th }}$ century, why do such divisions within Orthodoxy not have the same consequence? Kitromilides perceives the need to historicize the problem of collective mentalities, but converts the Braudelian concept of prisons de la longue durée into some very particular attributes of a small class of men. Meanwhile, the stress on Orthodoxy as a unifying factor contradicts his earlier, rather inspired assertion that " $18^{\text {th }}$ century Balkan society could be understood as a world of 
concentric and overlapping circles within a broader space whose human geography was defined by a multiplicity of languages and religious doctrines ${ }^{33}$.

One solution to the problem might be to conceive of "Balkan culture" less in terms of objective criteria, and more as an argument over meanings and definitions, advanced by particular people, in particular places, for particular purposes - existing as much in the imagination as in the marketplace, in the linguistic community or in seats of political power, and reconfigured in response to changing social, cultural and political processes ${ }^{34}$. This would mean thinking about how the region was understood and viewed by its inhabitants, as well as by outsiders, and asking not whether cultural identifications such as that of Cvijić were accurate, but what symbols they promoted, what images they projected, what interests they were meant to advance. Locallygenerated concepts of "Balkan culture" may have been in part the product of élite negotiations with notions of Europe, the Levant or the Orient, but they were not just simple appropriations. In every country comparable debates on identity produced particular theories, often in terms of a shared relationship with the outside world ; in every country these ideas have percolated into popular discourses. They covered a range of evaluations from the "stigmatic" to the "utopian" 35.

\section{West vs. East}

This leads us to another direction which became important in the 1990s : the study of "alterity", or otherness, generally seen as projected onto the region from without ${ }^{36}$. The critical study of Westerners' ideas and attitudes towards Eastern or South-Eastern Europe is not a new preoccupation. But various factors have given new importance to what was previously the domain of only a few researchers. The need to rethink the entire political order of Europe after events of 1989 formed the general background; new opportunities for Westerners to travel East, and experience the region at firsthand, led to a further need to challenge received and outdated ideas; an acutely-felt shortage of adequate literature and regional expertise in the West after that date could be cited as another cause. The outbreak of the Yugoslav conflict brought with it rumours that US policy was severely prejudiced by the essentialist opinions offered in a few sketchy travel books : it was clearly time for the imagologists and orientalists to move in and provide us with a clearer historical explanation of why Westerners think what they do about the East.

An important study in this direction was provided by L. Wolff which, using the works of Foucault and Edward W. Said in theoretical support, traced the origin of the idea of Eastern Europe to the writings of the philosophes and voyageurs of the (mainly French) $18^{\text {th }}$ century ${ }^{37}$. M. Todorova was wider in scope, covering writings from the $16^{\text {th }}$ century to the present day and presenting a case of remarkable polemical vigour against those who would generalize unguardedly about the characteristics of the inhabitants of the South-East ${ }^{38}$. V. Goldsworthy's book is basically of the same medicine but treats a specific version of the myopic condition, namely the representation of the Balkans in popular British fiction, travel writing and reportage ${ }^{39}$; while Kiril Petkov traced German perceptions of the Balkan "other" in medieval and early modern textual attitudes ${ }^{40}$.

All these works provided a justified and necessary critique of the way the West looks East. At the same time, however, we need to bear in mind the other half of the story. 
After all, it is not as if South-Eastern European writers are completely devoid of the tendency towards mythologization or ideological evaluation of the East-West divide. Recent critical studies of cultural mentalities from within the region have used similar theoretical premises to come to a completely different conclusion: that the tensions within "South-Eastern" or (to use the B-word) Balkan identities are often the result of local as much as Western, manipulations of geography and notions of civilization ${ }^{41}$. Where does the happy medium lie? And who is "inventing" whom?

21 A comparative study of, say, Voltaire's Histoire de Charles XII and Dimitrie Cantemir's History of the Ottoman Empire, would surely show that both North-Western and SouthEastern historians make use and abuse of "the map of civilization" - each for their own purposes, of course, but indisputably using comparable techniques. Likewise, ideologically motivated allegations of barbarism are not the exclusive intellectual property of the Western enlightenment. It was not just Bram Stoker who implicitly disparaged the nobility of the voevodes of the region; a Turkish chronicler is on record as describing John Hunyadi - with obvious political intent - as an « uncouth infidel peasant $»^{42}$.

To obtain a balanced picture of the role of literary discourse in shaping perceptions of the region we need to take into account more than just the West's - undeniably questionable - ideological role and interests. Moreover, cultural critiques of images of the region have paid remarkably little attention to important Russian and Ottoman perspectives ${ }^{43}$. A synthesis comparable to Bernard Lewis's brilliant book ${ }^{44}$, which could eventually chronicle Balkan attitudes to the outside, might help us to reach a more justly complex understanding of the problem. After all, as Montaigne pointed out long ago, we are all somebody's barbarians ${ }^{45}$.

Orientalist approaches nevertheless deserve credit for having problematized the popular notion of the Balkans, revealed its constructed (and arbitrary) quality, and examined new dimensions of the workings of power (certainly hegemonic, probably oppressive) that continue to animate and sustain the notion. Moreover, they raise very pointedly the question of how to do Balkan / South-East European studies at all - and whether South-Eastern Europe or the Balkans can be a useful category of analysis, given the "invented" quality of the concept and its political uses, let alone the fact that it is often a residual category, defined more by what it is not than by what it is. The academic enterprise of South-East European studies is unlikely to vanish overnight in a paroxysm of self-doubt, although the concept of area studies generally - not just that of our region - is being eroded with the end of Cold War imperatives ; criticisms of its lack of theoretical rigour; and a growing suspicion, in fields as far apart as rational choice theory and anthropology, of the concept of "culture" as a meaningful variable. Still, institutional interests, within and without both the academic milieu and the region itself, are likely to keep South-East European studies going, at least for the time being. Funding initiatives responding to continuing crises in the former Yugoslavia and their effect on the region as a whole, will doubtless prolong the income-generating life of the Balkan idea, albeit at the cost of re-defining and limiting the sort of work that is done under this rubric. Contestations between insiders and outsiders and between specialists and generalists over who is authorized to "do" South-East European studies will doubtless continue. The answer, however, should not be one-sided ${ }^{46}$; and one of the positive developments of the past decade has been an increasing degree of 
conversation, especially about methodology and outlook, between scholars working in the region and in the West. But the question still remains, is there any there there?

The Orientalist / post-colonialist / post-structuralist critique has no real answer to this question - or rather, it answers it, but in a way that is insufficient. If the imputed differences that define "the Balkans" are simply the markers or epiphenomena of power politics, then the implication can be that there is no reason to single out anything that is specifically Balkan. If the differentiation of Central Europe from territories "down there" in the Balkans is basically a matter of establishing hierarchies, and the signs of this difference are not important in themselves, what if anything does characterize the Balkans as a coherent or meaningful entity besides its image in the eye of others? For instance, it has been shown that the cleanliness of the inhabitants in South-Eastern Europe was a question subject to manipulative generalization by Westerners in the $19^{\text {th }}$ century ${ }^{47}$. Yet however ideologically-motivated or influential such descriptions may have been, they do not render the problem at hand - what was hygiene and sanitation like in $19^{\text {th }}$ century South-Eastern Europe? - either unanswerable or irrelevant in itself $f^{48}$. Since the Orientalist critique is really about the West, and since the Western construction of the Balkans is largely a by-product of its own process of self-definition, it is not very useful for thinking about South-Eastern Europe in itself. Or to put it another way, this approach focuses on the Balkans as the Other to the West, not on the Balkans as Self (except to the extent that it explores the ways people in the Balkans accept, internalize or contest Western definitions, on unequal terms - but this too is really about Western hegemony). In short, the Orientalist approach merely re-marginalizes the Balkans.

\section{Contributions}

The contributors to this issue have taken up these and other challenges, looking for ways to ways to go beyond a critique of "Balkanism", and suggesting other approaches to the study of the area. They profess, respectively, the disciplines of political science (George Schöpflin), history (Andrei Pippidi), anthropology (Pamela Ballinger), and literature (Vesna Goldsworthy) - although it would be an injustice to accuse any of them of inability to think about the region beyond their disciplinary specializations.

George Schöpflin, pondering South-Eastern Europe's distance from Western European norms of modernity, vigorously criticizes the post-structuralist critique's emancipatory promises; the condescending assumption that Western rationalism provides a universal explanatory model; and the absence in this approach of any way of understanding collective action. Posing the very useful question of why traditions, identities and myths have such power, he calls for a return to notions of common culture as animating and giving meaning to such identities, and he locates this culture in the specificities of South-East European history.

The political scientist's use of the notion of culture often necessitates that a compilation of characteristics - whose origin are not dated, whose standard deviation is not taken into account, and whose parameters are not given - be synthesized into an "average" model, which is then redistributed. Schöpflin presumes a common regional identity, attempts to define it with reference to selected traits, and posits a cultural unit with more or less permanent and impermeable boundaries. He then proceeds to use this definition as an analytical tool. But the traits which define South-Eastern 
Europe are not inherently obvious, nor peculiar only to the region. Any attempt to define South-Eastern Europe must provide a theory of both region and causation. Mere enumeration of internal characteristics is not sufficient, because for most of the last two thousand years it has been ruled from outside or from its margin, and because even theories of its homogeneity must account for its variegation, in time as well as in space. A comparative approach may suggest that a unique South-Eastern European culture does not necessarily underwrite South-East European exceptionalism ; and that SouthEastern Europe's role as a measuring-rod to Central Europe may not last. Schöpflin is right, however, not to treat the region as a tabula rasa which must passively await "transition" or "stabilization" from above - a common assumption among authors of projects for reform both within and without.

The discordances between the papers in this volume reconfirm that any number of configurations are possible, and that the choice often depends on political purposes. As Pamela Ballinger points out in her paper, the process becomes tautological : the same traits that are chosen to define the region then become proof of its cultural unity. In the end, this doesn't help us grasp Balkan cultural specificity, or situate it in relationship to other areas and histories, or understand Balkan mentalities. It just endorses the perceptions - and the politics - that we started out with.

One way out of this trap might be to conceive of "area" and of the Balkans / SouthEastern Europe as a heuristic device, defined for specific analytical or pedagogical purposes, its boundaries seen as intellectual constructs, provisional, open to question and over-lapping. This would have the advantage of interrogating definitions, traits and boundaries, rather than letting them pass unexamined. It would also make possible comparative work across areas, raising issues of what variables are pertinent, at what levels can comparisons be made, what differences and similarities are meaningful. And this in turn might yield more convincing accounts of what it is that is particular to the region. The same point might be made about more thematically-based research. But as Ballinger points out, even heuristic devices have a habit of becoming real (or institutionalized, which comes to much the same thing). They also, as Vesna Goldsworthy shows, can have real political consequences, whether intended or not. Furthermore, thematic topics can all too easily reproduce area definitions, so that area once again becomes explanation. Ballinger mentions post-socialism; discussions of gender and of nationalism often go the same way ${ }^{49}$.

Andrei Pippidi observes that some choose to emphasize the unity of the region, and others its diversity. His approach affirms a rigorous insistence on historical context, and focuses on the ideas and structures that are relevant at a particular time, in particular circumstances, to particular people. This avoids anachronistic reading into the past or tautological definitions, and gives us a way of thinking about specificity by comparing Balkan phenomena with similar patterns in Northern and Western Europe, with other Southern European peninsulas; by investigating specific definitions, identities and entities, their interrelations and their after-life as historical legacies. Many key models - for instance the opposition between Central and SouthEastern Europe - are assessed as to their age, their significance and their political valencies in different times. The models of the Balkans that are put forward are in many ways older than we think, but also subject to degrees of alteration over time, or "Changes of Emphasis", as Pippidi has called them. 

strive to emphasize the region's similarity to the West; while those who see the West and the South-East as separate often entertain a negative vision of the other party. But there should be room for both similarities and differences. A dolphin is not a fish : but a general description of that animal which noted only its similarity to mammals would be inaccurate. A key precondition of an adequate understanding of both regions will be a dissociation of the notions of "difference" and "resemblances" from moralizing rhetoric. As Schöpflin and Goldsworthy observe in their different ways, South-Eastern Europe will not necessarily be "better" if it is more like Western Europe. Nor will the latter immediately improve either by dissociating itself further from, or successfully assimilating, the former. It should be possible to recognize that the peace and welfare of the region is in the West's interests, but that tolerance or unity cannot be imposed from outside ${ }^{50}$. Comprehending what is particular about the phenomenon were are examining is necessary enterprise. South-East European studies face the same challenge as the wider post-colonialist project - finding ways of grasping historical specificity and particularity in a world where the definitions and the desiderata have generally been elaborated elsewhere. We have become accustomed to seeing the world as culturally and socially constructed, but with the emphasis on the drawing-board and the planner's office rather than on the construction site itself. We have, to an extent, lost sight of the cultural materials - and the craftsman's techniques - that make this whole process possible and informs it. Pointing an accusing finger at "the designs of Western hegemony" is not sufficient to explain the content or shape of cultures and societies that are thus built. Nor is it conducive to identifying factors of agency within the societies studied, particularly at the grass-roots level. How do we go about this?

An ongoing interrogation of the disciplines is essential. Are the fundamental questions of the present academic démarche adequate for our context? Not always, not entirely. The questions have been formulated in particular circumstances, and are not easily detachable from their contexts ${ }^{51}$. On the other hand, ideal types are not always designed for reprojection onto real maps. The task of "locating" our analytical concepts must be attended to prior to that of "describing" our objects of study ${ }^{52}$.

We need to take advantage of the possibilities of interdisciplinary work, and the advantages in sharpening methodological and theoretical assumptions by working across disciplines. Here the issue is to identify what sorts of problems provide the right framework for this sort of work. Fundamental is the set of issues around identity and the conditions of its production, through textual, structural, historical analyses. Given the function of the national as area-defining in our part of the world, differentiation in those terms is probably the starting point, but this needs to be understood in terms of the intersection of the national with other discourses ${ }^{53}$. And this necessarily then means more serious analyses of these other forms of identity: class, religion and gender, of course, but also individual, family, sexuality, profession, region.

This would open up a number of relatively unexplored issues. As historians, we note that the lack of serious social history of all kinds is a problem which affects scholars in all fields, whether they are political scientists looking to formulate paradigms, 
anthropologists trying to date the contemporary phenomena they are recording, or students of literature seeking a context for their texts. There has been all too little research on social groups, structures and processes. Marxist schools of history in the individual countries produced relevant work, but the focus on class struggle and progressive forces meant that entire spheres of human activity (women, nobility, the family, marginality) went largely unexplored. There were some stimulating attempts in the West to elaborate theories of society and social change in the region ${ }^{54}$. But these initiatives were not often followed up in detail, and South-East Europeanists only rarely attempted the sort of social and socio-political analysis that absorbed the Western historical profession in the 1970s and 1980s (perhaps partly because of the difficulties of archival research in the region). Western "history from below" sometimes approached the trivial, but the aspiration to a more total exploration of human experience was fruitful, and would certainly benefit our area. This is not to condemn the important study of states and élites, but it is difficult to know what states and élites are without considering their social consistency and the extent of their recognition. The harsh domination of ruling groups and the gap between state and society do not exclude extensive social mobility which needs to be studied ${ }^{55}$. Or, to turn a Balkan proverb on its head, not all fish rot from the head down.

On the other hand, a "Balkanocentric" vision of the world, which might try to suggest that only what is specific, unique or original to the region is relevant to its study, will fail to generate interesting conclusions. It is nearly twenty years since Katherine Verdery pointed out that even accounting for apparently compact and stable rural villages requires a long distance-view over centuries and regions : « with anything less, one cannot adequately render intelligible the actions of villagers or comprehend why their lives take the form they do ${ }^{56}$.

So comparative projects, within an area, and across regions. Even the most powerful, and the most oft-invoked "defining characteristics" of the region are not incomparable with other regions. The great so-called "legacies": the Ottoman, the Byzantine, the Communist, affected the region profoundly but also operated in other territories, and cannot be studied in their totality if South-East Europe is examined hermetically ${ }^{57}$. Characteristic "Balkan" institutions spread beyond the region: for instance, the Habsburg Empire's treatment of the Orthodox population in her southern confines owed more to the model of the Ottoman millet than to the example of her former Spanish possessions. There is no reason why attitudes to minorities, or violence, or the character of state-building in South-Eastern Europe cannot bear comparison with other situations in Europe, or for that matter South-East Asia or South America, although necessary care should be taken as to context ${ }^{58}$.

Some writing recently about Eastern Europe in general have remarked how the region perhaps may only be defined not in terms of common roots or an international culture but an atomization and a consciousness of distance from the West ${ }^{59}$. But solidarities are never so geometrical. Moreover, an ambiguous attitude to Europe can be found in Spain, Scandinavia and the British Isles, as well as in the Czech Republic. And to understand even Western or Central Europe requires an understanding of what is going on elsewhere ${ }^{60}$. South-East Europe, then, is not a mere reflection or defiant mirror held up to the North-West or the centre : for the mirror is in the minds of us all, wherever we come from ${ }^{61}$. It is not the opposite of "North-Western Asia" either. It is a reality whose meaning may be subject to normal contestation, but whose contentiousness does 
not have to be its most characteristic feature. The name we have chosen to examine, and to accept with all due disclaimers befitting a convention, benefits from being both provisional and specific ; arbitrary but also accurate ; distinct, but also connected to a wider world. South-Eastern Europe will always be part of what geographers have not yet called The Ural Pensinsula, namely Europe ; ignore it at your peril.

\section{NOTES}

1. Pseudo-Caesarius, Eratapokriseis (5th-6th C.), cited by Tapkova-Zaimova (Vasilika), « Entre le nord pontique et le Danube: mouvements des peuples historiques et légendaires à la haute époque ", Bulletin de l'AIESEE, 28-29, 1998-1999, p. 52.

2. McCrindle (J. W.), ed., The Christian Topography of Cosmas, an Egyptian Monk, London: Hakluyt Society (First Series, nr. 98), 1897, esp. pp. 40-41.

3. Hyde-Price (Adrian), in International Affairs, 75 (4), October 1999, p. 860, believes Croatia should be classified in Central Europe if it is good, and the Balkans if it is bad. He is slightly less extreme than Pseudo-Caesarius in his evaluation of these criteria, referring to " a poor human rights record and an authoritarian-nationalist character ».

4. Huntington (Samuel P.), The Clash of Civilizations and the Remaking of World Order, New York: Simon \& Schuster, 1996.

5. Most recently Pavlowitch (Stevan K.), A History of the Balkans, 1804-1999, London / New York : Longman, 1999.

6. Todorova (Maria), Imagining the Balkans, Oxford : Oxford University Press, 1997.

7. Halliday (Fred), Islam and the Myth of Confrontation, London : I.B. Tauris, 1995.

8. Kaplan (Robert),Balkan Ghosts. A Journey Through History, New York: St. Martin's, 1993. A ghostly coincidence : in 1988 J. Rupnik announced that «the spectre of Central Europe haunts the lands of "real socialism" » (Rupnik (Jacques), The Other Europe, London : Weidenfeld \& Nicolson, 1988, p. 4) ; in 1989,G. Schöpflin wrote that « the idea of Central Europe became, unquestionably, one of the spectres that came to haunt the politics of Europe as a whole in the 1980s. » (Schöpflin (George), "Central Europe : Definitions Old and New », in Schöpflin (George), Woods (Nancy), eds., In Search of Central Europe, Cambridge : Polity, 1989, p. 7), while in 1997 M. Todorova declared that « a specter is haunting Western culture - the specter of the Balkans » (Todorova (Maria), op.cit., p. 3). Marx would have been, if pleased to see his metaphor still hovering in the imagination, disappointed to find it applied to an ideology of region rather than one of class.

9. This buzzword was not unique to the Balkans, but drew on it. Some representative travel books : Nicolson (Adam),Frontiers. From the Arctic Circle to the Aegean, London: Weidenfeld and Nicolson, 1985 ; Malcomson (Scott L.),Borderlands : Nation and Empire, London / Boston : Faber \& Faber, 1993; Reid (Anna),Borderlands. A Journey through the History of the Ukraine, London: Weidenfeld \& Nicolson, 1997 ; Applebaum (Anne),Between East and West : Across theBorderlands of Europe, London : Papermac, 1995. Books entitled Between East and West number over one hundred titles in the last twenty-five years and deal with regions stretching from Moravia to Japan, via Bessarabia, Cyprus and the Suez Canal.

10. Wolff (Larry R.),Inventing Eastern Europe. The Map of Civilization on the Mind of the Enlightenment, Stanford: Stanford University Press, 1994; Goldsworthy (Vesna),Inventing Ruritania. The Imperialism of the Imagination, London / New Haven : Yale University Press, 1998. 
11. For "Nationalism"'s appearance on the front cover of Time magazine in 1990, see Nairn (Tom), "Demonizing Nationalism", London Review of Books, XV (4), 25 February 1993, p. 3. A recent survey of an increasingly saturated market in Smith (Anthony D.), Nationalism and Modernism, London / New York : Routledge, 1999.

12. Verdery (Katherine), "The Production and Defence of "the Romanian Nation", 1900 to World War II ", in Fox (Richard G.), ed., Nationalist Ideologies and the Production of National Cultures, Washington, DC: American Ethnological Association, 1990 (American Ethnological Society monograph series, no. 2) ; Herzfeld (Michael), Ours Once More : Folklore, Ideology and the Making of Modern Greece, Austin : Texas University Press, 1982 ;Čolović (Ivan), « Le folklore et la politique. Une affaire moderne », Revue des études sud-est européennes, 30 (3-4), 1992 ; Deletant (Dennis), Hanak (Harry), eds., Historians as Nation-Builders, London : SSEES / Macmillan, 1988.

13. Herzfeld (Michael), Anthropology through the Looking Glass, Cambridge : Cambridge University Press, 1987 ; Pearton (Maurice), « Notions of Nationalism », Nations and Nationalism, 2 (1), 1996.

14. Gellner (Ernest), " The Mighter Pen ? Edward Said and the double standards of inside-out colonialism », Times Literary Supplement, (4690), 19 February 1993, and ensuing correspondence in February 26, March 5, March 19, April 2, April 9, June 4 and June 111993.

15. Reviews in Carabott (Philip), Karakasidou (Anastasia) in European History Quarterly, 29 (3), July 1999, pp. 425-434 and Brown (Keith), « Review of Peter Mackridge \& Eleni Yannakakis, eds, Ourselves and Others. The Development of a Greek Macedonian Cultural Identity since 1913. Oxford 1997 », Byzantine and Modern Greek Studies, 23, 1999.

16. Cf. Roberts (Henry L.),Eastern Europe : Politics, Revolution and Diplomacy, New York : Alfred A. Knopf, 1970, pp. 3-15.

17. Misha Glenny's The Balkans, 1804-1999. Nationalism and the Great Powers (London: Granta, 1999)is only the most recent case in point. His claim (p. xxv) as to the absence of histories of the region set in international context does a disservice to the competence of more pedestrian but more accurate works such as Anderson (M.S.), The Eastern Question, 1774-1923 (London: Macmillan, 1968, rev. ed.), and Jelavich (Barbara),History of the Balkans (2 vols., Cambridge UP, 1983).

18. Norman Davies's Europe: A History (Oxford : Oxford University Press, 1996) made great play of expanding the historiographical horizon of Europe beyond the West but seriously ignored the South-East.

19. Hroch (Miroslav),Social Preconditions of the National Revival in Europe, Cambridge : Cambridge University Press, 1985, speaks merely of "insurrectional" nationalism in the Balkans. Gellner (Ernest),Nationalism, London: Weidenfeld \& Nicolson, 1997, pp. 41-43, admits that his theory linking nationalism to industrial development doesn't work well for the Balkans. The most thorough attempt to typologize East European nationalism to date is Sugar (Peter), «External and Domestic Roots of East European Nationalism » in Sugar (Peter), Lederer (Ivo), eds., East European Nationalism, Seattle : University of Washington Press, 1969.

20. This is especially true of textbooks of political history, e.g. Jelavich (Charles), Jelavich (Barbara),The Establishment of the Balkan National States, 1804-1920, Seattle : Washington University Press, 1977.

21. The position of those who see the Balkans in terms of its Ottoman legacy, e.g. Todorova (Maria), "The Ottoman Legacy in the Balkans » in Brown (L. Carl), ed., The Imperial Legacy. The Ottoman Imprint on the Balkans and the Middle East, New York : Columbia University Press, 1996.

22. The classic text is McNeill (William H.), Europe's Steppe Frontier, 1500-1800, Chicago : Chicago University Press, 1964 ; for some more recent work see Roksandić (Drago), ed., Microhistory of the Triplex Confinium, Budapest : Central European University Press, 1998.

23. See e.g. Lampe (John R.)Jackson (Marvin R.),Balkan Economic History, 1550-1950, Bloomington : Indiana University Press, 1982. See also Andrei Pippidi's article in this collection. 
24. Cf., on the idea of Central Europe, Péter (László), « Central Europe and its reading into the past ", European Review of History, 6 (1), 1999.

25. The list could be endless: see more recently, Zanić (Ivo),Prevarena povijest (L'histoire détournée), Zagreb : Durieux, 1998 ; Boia (Lucian),Istorie şi mit în conştiinţă românească (L'histoire et les mythes dans la constitution de la roumanité), Bucureşti : Humanitas, 1997 ; Žirojević (Olga), « Kosovo u istorijskom pamcenju (mit, legende, ćinjenice) » (Le Kosovo dans la mémoire historique, mythe, légende, faits), Republika, 7, 15/03/95, etc.

26. Malcolm (Noel),Bosnia: A Short History, London: Macmillan, 1996; idem., Kosovo: A Short History. With a New Preface, London: Macmillan, 1999. Cf. the balanced critique of Winnifrith (Tom), Shattered Eagles, Balkan Fragments, London : Duckworth, 1995, pp. 7-9.

27. Cvijić (Jovan),La Péninsule Balkanique, Paris: J. Gamber, 1918; cf. his adaptor, Tomašić (Dinko), Društveni razvitak Hrvata (Le développement social des Croates), Zagreb: Naklada hrvatska, 1937. Iorga (Nicolae), Le caractère commun des institutions du sud-est de l'Europe, Paris : J. Gamber, 1929.

28. Stoianovich (Traian),Balkan Worlds. The First and Last Europe, Armonk / New York: M.E. Sharpe, 1994.

29. Kitromilides (Paschalis M.), «"Balkan mentality" : history, legend, imagination ", Nations and Nationalism, 2 (2), 1996.

30. Ibid., pp. 171.

31. There is not the space to discuss them in detail here, but some similar problems are raised by A. DuŢu's equally stimulating contribution, DuŢu (Alexandru), «Y a-t-il une Europe orthodoxe? Leçons faites au Collège de France ", Sud-Estul şi contextul european. Cultură şi solidarităŢi în „Europa Ortodoxă". Buletinul institutului de studii sud-est europene, 7, 1997.

32. One could cite the Slavonic menaion of 1761 entitled Srbljak, which structured a year of worship around specifically Serbian saints; or the prefaces to the menaia published by Bishop Chesarie and his successors at Râmnic in the 1770s and 1780s, which did much the same for the Wallachians; not to mention Paisii Hilendarski's Istoriya slavenobolgarskaya completed in 1762.

33. Kitromilides (Paschalis M.), art.cit., p. 168.

34. For example, D.Rihtman-Auguštin gives a stimulating account of Croatian shifts in and out of Balkans in the 20th century (Rihtman-Auguštin(Dunja), «Zašto i otkad se grozimo Balkana » (Pourquoi et depuis quand abhorrons-nous les Balkans), Erasmus, 19, 1997.

35. S. Antohi has used these concepts to study different facets of the Romanian social imaginary: see Antohi (Sorin),Imaginaire culturel et réalité politique dans la Roumanie moderne, Paris: L'Harmattan, 1999. His theoretical framework could be profitably used in study of collective identity elsewhere in the region.

36. Some remarks on the development of the field, and welcome suggestions for further research, in Todorova (Maria), «L'image de l'autre », Bulletin de l'AIESEE, 28-29, 1998-1999. The following five paragraphs are somewhat revised from Drace-Francis (Alex), «Inventions and Intentions : Miscellaneous Remarks on South-Eastern Europe and the New Discourse History ", South-East European Newsletter (London : SEESA), 39, October 1998.

37. Wolff (Larry), Inventing Eastern Europe: The Map of Civilization on the Mind of the Enlightenment, Stanford University Press, 1994. See Andrei Pippidi's article in this number for a nuanced evaluation of this claim.

38. Todorova (Maria), Imagining the Balkans, Oxford University Press, 1997. Themes already foreshadowed in Allcock (John B.), "Constructing the Balkans », in Allcock (John B.), Young (Antonia), eds., Black Lambs and Grey Falcons. Women Travellers in the Balkans, Bradford: Bradford University Press, 1991.

39. Goldsworthy (Vesna), Inventing Ruritania, Yale, 1998.

40. Petkov (Kiril), Infidels, Turks and Women : The South Slavs in the German Mind, ca. 1400-1600, Peter Lang, 1997. 
41. For ideas of "The Balkans" and "The West" within Yugoslavia and her sucessor-states, see Bakić-Hayden (Milica),Hayden (Robert), "Orientalist Variations on the Theme "Balkans": Symbolic Geography in Recent Yugoslav Cultural Politics », Slavic Review, 51 (1), 1992 ; and BakićHayden (Milica), « Nesting Orientalisms : The Case of Former Yugoslavia », Slavic Review, 54 (4), 1995. A recent collection of articles (some in Western languages) on Romanian visions of "others" in : Zub (Al.), ed., Identitate şi alteritate în spaţiul românesc, Iaşi : Univ. „Al. I. Cuza”, 1996.

42. Iorga (Nicolae), "Cronicele turcești ca izvor pentru istoria românilor », Academia Română. Memoriile secţiunii istorice, 3 (9), 1928-1929, p. 12.

43. Shaw (Stanford), "The Ottoman view of the Balkans", in Jelavich (Charles), Jelavich (Barbara), eds., The Balkans in Transition, Berkeley : California University Press, 1963, deals mainly with political considerations in the Middle Ages. A great deal of work has been done on Russia's diplomatic and military role in the Balkans, but very little of value on cultural similarities and differences. Brower (Daniel R.),Lazzerini (Edward J.), eds., Russia's Orient : Imperial Borderlands and Peoples, 1700-1917. Bloomington: Indiana University Press, 1997, opens up some useful perspectives.

44. Lewis (Bernard), The Muslim Discovery of the West, London : Weidenfeld and Nicolson, 1982. Reprinted by Phoenix, London 1994.

45. See Pippidi (Andrei), «Naissance, renaissances et mort du "bon sauvage" : à propos des Morlaques et des Valaques" in Hommes et idées du Sud-Est européen à l'aube de l'âge moderne, Bucureşti : Editura Academiei / Paris : Editions du C.N.R.S., 1980.

46. Balamaci (Nicholas S.), "Can the Vlachs Write Their Own History? », Journal of the Hellenic Diaspora, 17, 1991; cf. Chakrabarty (Dipesh), « Postcoloniality and the artifice of history: Who speaks for "Indian" pasts?", Representations, 37, 1992.

47. Rivals were dirty ; protégés cleanly, or « though not as yet tidy, they are particularly anxious to become so". Bracewell (Wendy), "Opinion-makers: the Balkans in British Popular Literature, 1856-1876 », in KaČavenda (Petar), ed., Jugoslovensko-britanski odnosi / British Yugoslav Relations, Beograd : Institut za savremenu istoriju, 1988, pp. 101-102.

48. See, e.g., Panzac (Daniel), La peste dans l'Empire Ottoman, 1700-1850, Leuven : Editions Peeters, 1985.

49. Much work on "Mediterranean" masculinity suffers from this tendency : see e.g. Gilmore (David D.), ed., Honor and Shame and the Unity of the Mediterranean, American Anthropological Association, no. 22. Washington DC, 1987 ; cf. for the Balkans, Dzadzić (Petar), Homo balcanicus, homo heroicus, Belgrade : BIZG, 1987. The same could be said of "eastern" and "western" models of nationalism : e.g. Plamenatz (John), "Two types of nationalism », in Kamenka (Eugene), ed., Nationalism: The Nature and Evolution of an Idea, London : Edward Arnold, 1973 ; and E. Gellner's “zones" of nationalism in Europe, most recently in Gellner (Ernest),Nationalism (op.cit.), pp. $50-58$.

50. Cf. the judicious thoughts of Mazower (Mark), « Tolérance et intolérance dans les Balkans », Revue des Deux Mondes, (11-12), novembre-décembre 1999; and the singularly injudicious ones of Kadaré (Ismail), « Ecrire une histoire nouvelle des Balkans », ibid.

51. An interesting example is the term "Renaissance", which was first used in French in 1554 to denote a revival of Greek learning within the Ottoman Empire; but later came to define that surge in Western cultural confidence which had begun earlier and which the Greeks were subsequently condemned for not having undergone. Huppert (George), The Style of Paris. Renaissance Origins of the French Enlightenment, Bloomington : Indiana University Press, 1999 (citing Belon (Pierre), Les Observations de plusieurs singularités et choses mémorables trouvés en Grèce, Asie, Judée, Arabie et autres pays estranges, Paris, 1554).

52. Bhabha (Homi), The Location of Culture, London : Routledge, 1994.

53. Duţu (Alexandru),Political Models and National Identities in "Orthodox Europe", Bucharest: Babel, 1998. 
54. E.g. Stoianovich (Traian), "The Social Foundations of Balkan Politics, 1750-1945 ", in Jelavich (Charles), Jelavich (Barbara), eds., The Balkans in Transition (op.cit.), pp. 295-341; Stokes (Gale), "The Social Origins of East European Politics ", in Chirot (Daniel), ed., The Origins of Backwardness in Eastern Europe. Economics and Politics from the Middle Ages until the Early Twentieth Century, Berkeley / Los Angeles / Oxford : California University Press, 1989; Beck (Sam),Cole (John), eds., Ethnicity and Nationalism in Southeastern Europe, Amsterdam: University of Amsterdam, 1981.

55. Codarcea (Cristina), "Le caractère de l'Etat valaque. Quelques considérations », in LaurenŢiu (Vlad), ed., Pouvoirs et mentalités. Textes réunis à la mémoire du Professeur Alexandru DuŢu, Bucarest: Babel, 1999 ; LeDonne (John P.), Absolutism and the Ruling Class. The Formation of the Russian Political Order, Oxford : Oxford University Press, 1991, pp. 3-60.

56. Verdery (Katherine),Transylvanian Villagers. Three Centuries of Political, Economic and Ethnic Change, Berkeley / Los Angeles / Oxford: University of California Press, 1983, p. 2.

57. Among many studies of these "legacies", one might mention: Runciman (Steven), The Great Church in Captivity, Cambridge : Cambridge University Press, 1968; Brown (L. Carl), ed., op.cit. (esp. in this last volume essays by Maria Todorova and Halil Inalcik discuss what "legacy" might mean); Schöpflin (George),Politics in Eastern Europe, 1945-1992, Oxford / New York: Blackwell, 1993.

58. Some useful remarks on comparing Slovenia with Wales in Okey (Robin), "Education and Nationhood in Wales, 1850-1940", in Tomiak (Janusz) et al, eds., Schooling, Educational Policy and Ethnic Identity, Aldershot: Dartmouth / New York: New York University Press (Comparative Studies on Governments and Non-dominant Ethnic Groups in Europe, 1850-1940. Vol. I), 1991, pp. 35-62.

59. "The dialogue about an eventual all-European cultural identity is entirely a West European affair which so far does not address us in the East. » (Kusý (Miroslav), «We, Central-European East Europeans ", in Schöpflin (George), Woods (Nancy), eds., op.cit., p. 96). Cf. R. Pynsent and S.Kanikova who remark that a sense of Europe as something external is one of the few unitary characteristics of East European literature: Pynsent (R. B.),Kanikova (S.I.), "Preface", The Everyman Companion to East European Literature, London : J.M. Dent, 1993, p. vii.

60. Anderson (Perry), « The Central Europe Problem », London Review of Books, 25 (20), 25/11/99.

61. Hartog (François), Le miroir d'Hérodote. Essai sur la représentation de l'autre, Paris : Gallimard, 1980 (see also English translation by Janet Lloyd published by University of California Press, 1987).

\section{AUTEUR}

\section{WENDY BRACEWELL AND ALEX DRACE-FRANCIS}

Wendy Bracewell is Senior Lecturer in History at the School of Slavonic and East European Studies, University College London ; and director of the Centre for South-East European Studies there. Alex Drace-Francis is a PhD candidate and teaching assistant and the School of Slavonic and East European Studies, University College London. 